\title{
PERANCANGAN GEOGRAPHIC INFORMATION SYSTEM UNTUK TRACKING DAN ROUTING MENGGUNAKAN ALGORITMA DIJKSTRA PADA KENDARAAN ANGKUTAN UMUM
}

\author{
Muh. Aristo Imdrajaya \\ Fakultas Teknik, Jurusan Teknik Elektro, Universitas Tadulako \\ Email : aristo@untad.ac.id
}

\begin{abstract}
The ability to do tracking and routing of a motorized vehicle is very useful in everyday life, such as security on private vehicles, public transportation systems, mass transportation fleet management and others. In this study, we designed a Geographic Information System (GIS) application that will be applied to public transport services. This system will in real time track the position of each vehicle (taxi) and be able to perform automatic service for every taxi request by the customer.

Dijkstra's algorithm is a graph search algorithm that solves the shortest path problem that originates from one node for a graph where the weight of the node must not be negative. The analysis is done by examining the node with the smallest weight and inserting it into the set of solutions with the initial search for the origin node requiring knowledge of all paths and weights. Dijkstra's algorithm which is applied to this system will function to find the most suitable taxi for customers by using distance parameters and traffic density levels as the weight value.
\end{abstract}

Keywords: GPS, GIS, GSM, Dijkstra, TCP / IP

\section{Pendahuluan}

Pertumbuhan jumlah kendaraan secara global diperkirakan akan semakin meningkat seiring dengan pertumbuhan ekonomi serta jumlah masyarakat kelas menengah yang semakin meningkat, seperti di Cina dan India. Meskipun pertumbuhan jumlah kendaraan selain memberi dampak positif yaitu semakin bertambahnya jumlah penduduk kelas menengah keatas, akan tetapi pengembangan sistem pelacakan (tracking) dan perutean (routing) suatu kendaraan yang juga merupakan bagian yang sangat penting pada sebuah sistem transportasi masih sangat kurang. Penggunaan sistem tracking dan routing pada mode transportasi akan sangat bermanfaat untuk berbagai macam aspek termasuk aspek keamanan maupun ekonomi pada kendaraan pribadi, sistem transportasi masal, kendaraan niaga dan lain sebagainya. Untuk angkutan penumpang dan barang, sistem tracking dan routing ini dapat digunakan untuk melakukan menejemen terhadap armada angkutan khususnya untuk pengaturan terhadap rute yang akan dilalui sehingga akan meningkatkan efisiensi terhadap waktu tempuh dan pemakaian bahan bakar yang harganya terus mengalami lonjakan.

Di sisi lain, sistem navigasi GPS (Global Positioning System) telah diadopsi secara luas sebagai sistem navigasi kendaraan saat ini dan harganya kian terjangkau. Perangkat ini digunakan oleh pengemudi untuk membantu menemukan tujuan mereka melalui instruksi instruksi. Sistem GPS ini juga akan dapat digunakan untuk melakukan tracking terhadap posisi suatu kendaraan berdasarkan pembacaan koordinatnya dan dengan menganalisa data dari GPS, kecepatan sebuah kendaraan juga dapat diketahui dengan pasti. Dengan membangun aplikasi GIS (Geographic Information System) berbasis web, maka posisi dan kecepatan suatu kendaraan dapat diketahui melalui perangkat mobile yang terhubung ke internet.

Tujuan utama dari penelitian kami adalah membangun sebuah sistem yang mampu melacak posisi suatu kendaraan secara otomatis (automatic vehicle location tracking system) yang dapat menunjang kinerja angkutan penumpang khususnya armada taksi. Pada umumnya penyedia layanan taksi masih menggunakan metode manual dengan mengandalkan pemancar radio untuk memberikan informasi mengenai pemesanan taksi kepada pengendara yang dilakukan oleh seorang operator. Hal ini menyebabkan belum adanya konfirmasi taksi mana yang akan melayani pemesanan taksi nantinya serta memperpanjang waktu pelayanan utamanya di jam-jam sibuk. Pencarian taksi terdekat untuk 
pemesan taksi terdekat juga tidak bisa dilakukan tanpa mengetahui lokasi pemesan taksi secara otomatis.

Dengan menggunakan sistem ini, selain posisi setiap taksi akan terpantau melalui sebuah aplikasi GIS (Geographic Information System) berbasis web, sistem ini akan mampu melakukan pemilihan taksi yang paling layak diberikan kepada pelanggan berdasarkan data posisi kendaraan dan tingkat pendapatan dari tiap pengendara taksi sehingga akan memberikan keuntungan bukan hanya bagi calon penumpan saja tapi juga bagi pengendara itu sendiri yang akan berdampak pada pemerataan pendapatan bagi tiap - tiap pengendara taksi.

\section{Metode Penelitian} tahapan berikut :

Penelitian yang dilakukan memiliki

\section{a. Perancanaan sistem secara umum}

Pada tahapan ini dilakukan perencanaan mengenai komponen apa saja yang diperlukan dalam pembuatan sistem ini seperti tipe perangkat GPS receiver serta sistem operasi yang akan digunakan pada unit server. Selain itu diperhitungkan pula mengenai parameter apa saja yang menentukan kinerja dari sistem yang akan dibangun. Desain dari sistem yang dibangun dapat dilihat pada Gambar 3.2.

\section{b. Instalasi web server dan database server}

Pada tahapan ini dilakukan proses instalasi terhadap server yang akan berfungsi menampilkan aplikasi peta berbasis web serta menyiapkan server yang berfungsi sebagai database bagi sistem yang dirancang. Aplikasi yang akan dipasang pada server adalah Apache untuk menjalankan aplikasi http dan MySql untuk menjalankan aplikasi database. Server yang akan digunakan akan memiliki ip public sehingga dapat diakses secara online.

\section{c. Pembuatan aplikasi monitoring pada pada perangkat GPS}

Pada tahap ini, dibangun aplikasi yang mampu melakukan data acuisition terhadap data posisi dan kecepatan dari tiap - tiap kendaraan. Selain itu aplikasi ini akan mampu mengirimkan data yang telah didapatkan menuju server menggunakan melalui jaringan GSM dan data akan dikirimkan menuju server dalam bentuk TCP packet. Aplikasi ini akan di install pada perangkat GPS berupa smartphone dengan sistem operasi Android dengan menggunakan bahasa pemrograman Java. Sebuah smartphone yang telah mengaplikasikan sistem GPS akan mampu melacak posisi dengan baik dan dapat diterapkan sebagai perangkat tracking pada sistem transportasi umum [10].

\section{d. Pembuatan aplikasi GIS berbasis web.}

Pada tahapan ini dibangun sebuah aplikasi GIS (Geographic Information System) yang berfungsi menampilkan secara mendetail setiap posisi dan kecepatan dari kendaraan yang dipantau melalui layanan berbasis web serta memberikan akses bagi calon pelanggan yang ingin melakukan pemesanan taksi. Aplikasi ini akan dijalankan pada unit server yang telah memiliki ip public sehingga dapat diakses dimana saja dengan menggunakan perangkat mobile. Seorang pelanggan yang akan melakukan pemesanan angkutan atau taksi dapat mengakses sistem ini secara online. Ketika pelanggan telah memasukkan posisinya saat ini, maka aplikasi ini akan langsung mencari taksi dengan posisi terdekat dari penumpang menggunakan Algoritma Dijkstra.

\section{e. Pengujian Sistem}

Setelah sistem selesai dibangun, tahap selanjutnya adalah dengan melakukan pengujian dari sistem yang dibangun ini. Pengujian ini dilakukan untuk mengetahui keakuratan dari kecepatan dan posisi kendaraan yang berhasil dilacak, besarnya delay yang terjadi ketika pengiriman data dilakukan dari kendaraan menuju ke server serta mengetahui waktu yang diperlukan oleh sistem untuk melakukan reponse terhadap setiap permintaan oleh pelanggan. 
III. Hasil dan Pembahasan.

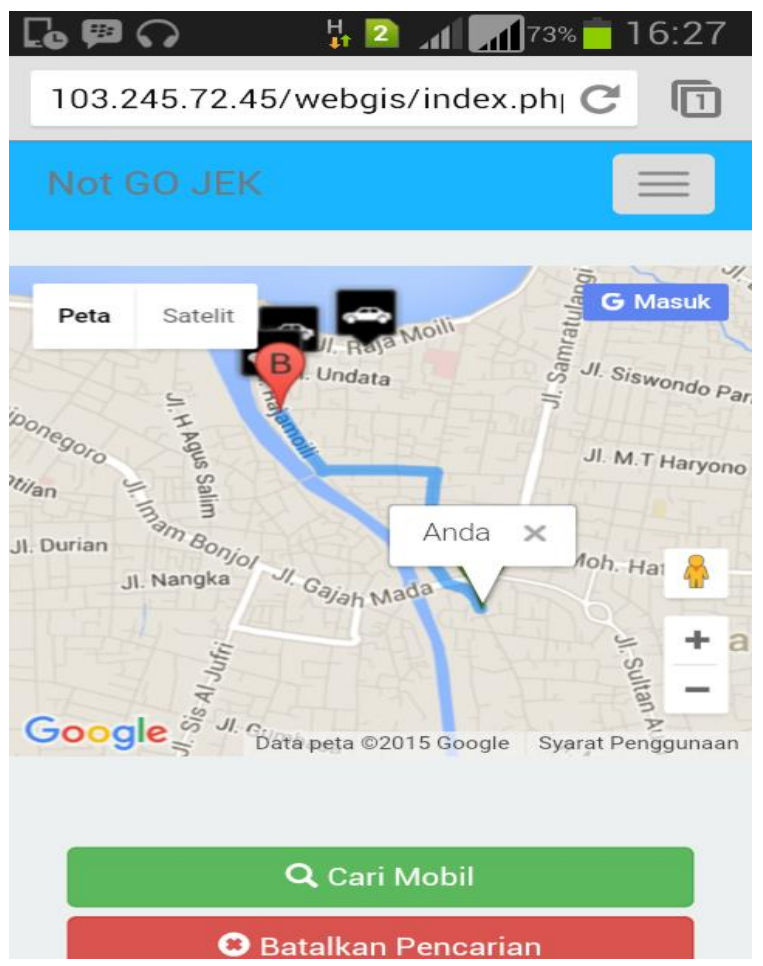

Gambar 1. Aplikasi GIS yang dibangun.

Interface dari sistem yang telah dibangun dapat diakses melalui layanan berbasis web. Ketika sistem telah diakses dan penumpang telah setuju dengan transaksi yang telah dilakukan maka sistem akan melakukan pencarian dengan posisi paling dekat dari pelanggan seperti yang dapat dilihat pada Gambar 1.

Sistem akan mengirimkan notifikasi berupa alamat dari pelanggan kepada pengemudi taksi melalui layanan berbasis push e-mail seperti yang dapat dilihat pada Gambar 4.2. Melalui layanan ini pengemudi taksi dapat memilih untuk menerima atau menolak pemesanan. Jika pengemudi menolak, maka sistem dapat melakukan pencarian kembali taksi terdekat. Setiap tanggapan yang

dilakukan oleh pengemudi taksi baik menerima atau menolak order, pelanggan akan menerima tanggapan dari sistem melalui layanan SMS (Shor Message Service).

Proses yang berjalan pada sistem yang dibangun ini dapat dipahami dengan mengikuti skenario pengujian berikut. Pengujian dilakukan dengan melibatkan tujuh orang yang terdiri dari enam orang yang bertindak sebagai pengendara taksi dan satu sebagai pelanggan. Posisi dari pengendara disebar ke berbagai sudut kota untuk menyesuaikan dengan kondisi yang terjadi sehari-hari.
Data posisi terbaru dari penumpang dan pengendara taksi yang berupa data latitude dan longitude disimpan di dalam database pada server yang digunakan. Di dalam database akan ditampung posisi seluruh taksi, jarak antara tiap taksi satu sama lain dan jarak antara tiap taksi dengan pelanggan yang melakukan transaksi.

\section{Kesimpulan}

1. Algoritma Dijkstra yang diterapkan pada sistem yang dibangun mampu melakukan pencarian node atau taksi dengan kriteria terbaik dengan waktu rata-rata 0,3911 detik.

2. Jumlah node atau taksi yang ada akan mempengaruhi seberapa cepat sistem yang dibangun mampu melakukan pencarian node atau taksi yang paling tepat bagi pelanggan.

3. Penambahan parameter tingkat kepadatan selain parameter jarak yang telah digunakan sebelumnya serta penggunaan Algoritma MDSP yang merupakan modifikasi dari Algoritma Dijkstra pada sistem yang dibangun mampu memberikan hasil yang lebih valid dalam pencarian node taksi.

\section{Daftar Pustaka}

1. Almomani, I.M., et al. (2011), "Ubiquituous GPS Vehicle Tracking and Management System", IEEE Jordan Conferences on Applied Electrical Engineering and Computing Technologies (AEECT).

2. Aloquili, O., Elbanna, A., Al-Azizi, A. (2009), "Automatic Vehicle Location Tracking System Based on GIS Environment", The Institution of Engineering and Technology, Vol. 3, No. 4, hal. 255-263.

3. Cho H.J., \& Cho M., (2013), "Effective Position Tracking Using B-Spline Surface Equation Based on Wireless Sensor Networks and Passive UHF-RFID”, IEEE Transactions on Instrumentation and Measurement, Vol. 62, No. 9.

4. Dat, H. P., Drieberg, M., Cuong, C.N. (2013), "Development of Vehicle Tracking System using GPS and GSM Modem". IEEE Conference on Open Systems, Sarawak. 
5. Davis, S. (2007), GIS for Web Developers, The Pragmatic Programmers.

6. Gintoro, Iwan Wijaya Suharto, et al. (2010), "Analisis dan Perancangan Sistem Pencarian Taksi Terdekat Dengan Pelanggan Menggunakan Layanan Berbasis Lokasi”. Seminar Nasional Aplikasi Teknologi Informasi, Yogyakarta.

7. Jerath K., \& Brennan, N. (2012), "GPS Free Train-Based Vehicle Tracking on Road Networks", American Control Confrence, Faimont Queen Elizabeth, Montreal.

8. Johnson, M.C., \& Thomas, L.E. (2000), Automatic Vehicle Location Successful Transit Aplications, U.S. Department of Transportations, Washington, DC.

9. Joyner, D., Nguyen V.H., Cohen, N. (2011), Algorithmic Graph Theory.

10. Lammle, T., (2007), Cisco Certified Network Associate Study Guide, Wiley Publishing, Inc., Indianapolis.

11. Lee, S., Tewolde, G., Kwon, J., (2014), "Design and Implementation of Vehicle Tracking System Using GPS/GSM/GPRS Technology and Smartphone Application", IEEE World Forum on Internet of Things.

12. McWilliam, N., et al. (2005), GIS, GPS and Remote Sensing, The Expedition Advisory Centre Royal Geographical Society 1 Kensington Gore, London.

13. Menard, T., et al. (2011), "Comparing The GPS Capabilities of The Samsung Galaxy S, Motorola Droid X, and The Apple iPhone for Vehicle Tracking Using Freesim Mobile", International IEEE Conference on Intelligent Transportation System, Washington, DC.

14. Menard, T., \& Miller, J., (2011), "Comparing The GPS Capabilities of The iPhone 4 and iPhone 3G for Vehicle Tracking Using FreeSim_Mobile", IEEE Iintelligent Vehicles Symposium, BadenBaden.

15. Odom, W., (2007), CCENT/CCNA ICNDI Official Exam Certification Guide, Cisco Press, Indianapolis.

16. Sathiamoorthy, M. (2009), “On GPS Tracking of Mobile Devices", International Conference on Networking and Services".

17. Sivakumar, S., \& C. Chandrasekar. (2014), Modified Dijkstra's Shortest Path Algorithm", International Journal of Innovative Research in Computer and Communication Engineering, Vol. 2.

18. Yi Z., Ding W., Yanfei Y. (2009), "On Dynamic Scheduling of Vehicles Based on GPS / GIS / RFID", Department of Computer Science \& Technology, Harbin.

19. Yuan G., et al. (2008), "Research and Design of GIS in Vehicle Monitoring System", Internation Conference of Internet Computing in Science and Engineering. 